\title{
Association of HLA-B35 with mucocutaneous lesions in Israeli patients with rheumatoid arthritis receiving gold treatment
}

\author{
M TISHLER, ${ }^{1}$ D CASPI, ${ }^{1}$ E GAZIT ${ }^{2}$ AND M YARON ${ }^{1}$ \\ From the 'Department of Rheumatology, Tel Aviv Medical Center, Tel Aviv; and the ${ }^{2}$ Tissue Typing \\ Laboratory, Chaim Sheba Medical Center, Tel Hashomer, and the Tel Aviv University Sackler School of \\ Medicine, Israel
}

SUMmARY Seventy four Israeli patients with rheumatoid arthritis (RA) were studied for possible association between HLA antigens and adverse reactions to gold treatment (aurothioglucose). HLA-B35 was significantly increased in patients who developed gold induced mucocutaneous lesions. These results are in accord with earlier reports, despite the different genetic background of the Israeli RA population and the different type of gold compound used.

Key words: dermatitis, gold toxicity.

Numerous works have shown that genes in the HLA system are associated with susceptibility to a number of diseases, including rheumatoid arthritis (RA). ${ }^{1}$ The frequency of DR4 was found to be increased in most RA populations studied, ${ }^{2}{ }^{3}$ and it has been suggested that certain DR antigens, especially DR3, are related to drug toxicity. ${ }^{4}$ Recently it has also been observed in patients with RA treated with sodium aurothiomalate that class I antigens (B35 and $\mathrm{Cw} 4)$ are associated with the development of nephritis and dermatitis. ${ }^{56}$ We have previously reported that HLA-DR1 and not DR4 is associated with RA in Israeli patients, ${ }^{7}$ as opposed to other Caucasian populations. The type of gold used by us (sodium aurothioglucose) is also different from the preparations studied previously. We report the relation between HLA and gold salt toxicity in Israeli patients.

\section{Patients and methods}

This study was carried out on 74 patients from the outpatient clinic of the department of rheumatology, Ichilov Hospital. All patients were classified as having definite or classical RA according to the American Rheumatism Association criteria. Patients were assessed clinically, and specific atten-

Accepted for publication 9 September 1987.

Correspondence to Dr M Tishler, Department of Rheumatology, Ichilov Hospital, Tel Aviv, Israel 64239. tion was paid to drug history, including response and adverse reactions, presence of extra-articular manifestations, and Sjögren's syndrome. Results of routine haematological and biochemical tests and the presence of rheumatoid factor (RF) and antinuclear factor were recorded for each patient.

Patients had been treated for up to 10 years with sodium aurothioglucose (Solganal, Schering, Berlin). Gold was given by the following regimen: test doses of $10 \mathrm{mg}$ and $25 \mathrm{mg}$ one week apart, $50 \mathrm{mg}$ doses for 20 consecutive weeks, maintenance regimen of 50 $\mathrm{mg} / 2$ weeks for three months and $50 \mathrm{mg} / 3-4$ weeks indefinitely. Mucocutaneous lesions consisting of a maculopapular rash or aphthous stomatitis were considered to be due to gold therapy when they appeared during treatment and disappeared after gold treatment was discontinued.

HLA TYPING

HLA-A, B, C antigens were determined by the microlymphocytotoxicity technique. ${ }^{8}$ HLA-DR typing was performed on $T$ cell depleted $B$ cell enriched lymphocytes by extended incubation cytotoxicity testing. ${ }^{9}$ The HLA antigen frequency was compared with that of healthy controls typed by the same laboratory.

STATISTICAL ANALYSIS

Differences between groups were compared by the $\chi^{2}$ test with Yates's correction. The relative risk 
(RR) was calculated according to Woolf's equation. The $p$ value was corrected for the number of tested antigens $\left(p_{c}\right)$.

\section{Results}

Table 1 summarises the demographic and clinical data of patients with (group A) and without (group B) gold salt toxicity. There were no significant differences between the groups with respect to age, sex, disease duration, and the presence of rheumatoid factor.

Thirty four of 74 patients who received gold treatment developed side effects: 20 had mucocutaneous reactions, nine proteinuria, and five developed haematological abnormalities (leucopenia or thrombocytopenia). Gold induced mucocutaneous toxic reactions were observed after a mean (SD) of 4.6 (4.4) months. Two patients had two or more adverse reactions simultaneously.

HLA-A, B, C (class I), and DR (class II) antigen frequencies in 74 patients with and without adverse reactions to gold were compared with those of the control population (Table 2). No significant difference was found in the frequency of HLA antigens when patients with RA and no side effects (group B) were compared with healthy controls (group C). In contrast, patients with gold induced mucocutaneous lesions had an increased frequency of the HLA-B35

Table 1 Clinical characteristics of patients with $R A$ with (group A) and without (group B) side effects

\begin{tabular}{lll}
\hline & $\begin{array}{l}\text { Group A } \\
(n=34)\end{array}$ & $\begin{array}{l}\text { Group B } \\
(n=40)\end{array}$ \\
\hline Age (mean (SD)) (years) & $58(11 \cdot 2)$ & $60(13 \cdot 4)$ \\
M/F ratio & $1: 3 \cdot 5$ & $1: 3 \cdot 3$ \\
Disease duration (mean (SD)) & $6 \cdot 1 \quad(3 \cdot 7)$ & $5 \cdot 6 \quad(4 \cdot 2)$ \\
$\quad$ (years) & 71 & 68 \\
RF positive (\%) & 23 & 25 \\
ANF positive (\%) & & \\
\hline
\end{tabular}

antigen as compared with groups $\mathrm{B}$ or $\mathrm{C}\left(\mathrm{p}_{\mathrm{c}}<0.05\right) \stackrel{\text { ? }}{\text { ? }}$ HLA antigen frequencies were similar in the othe side effect groups and did not differ statistically from those of groups B and C.

RA patients having HLA-B35 were calculated to have an increased relative risk of $3 \cdot 1$ of developin gold induced mucocutaneous lesions as compare with B35 negative patients.

\section{Discussion}

The association between HLA-DR2 and DR3 and toxic reactions to gold and penicillamine in patient $\overline{\mathrm{S}}$ with RA was first suggested by Panayi and Wooley. $\stackrel{\nexists}{-}$ Since then many reports with conflicting results haves been published. Although some authors found no correlation between HLA-DR antigens and golgr toxicity, ${ }^{10}$ other studies described significant asso ${ }^{-}$ ciations with B8 and DR3. ${ }^{11-13}$ Gold salt dermatitis has recently been related to class I B35 antigen, thus adding further information to the possible genetic factors associated with various adverse. reactions. Similarly, our results show that patient\$o with RA carrying the HLA antigen B35 were at a greater risk $(R R=3 \cdot 1)$ of developing mucocutaneoug reactions to gold. We did not observe an increase ir the frequency of B35 among patients with RA having other gold induced side effects. In contrasô with other works, our patients with RA carrying the HLA antigens DR3 and B8 were not more prone to develop toxic reactions to gold. The differen $\bar{E}$ genetic background of the Israeli population, $i \bar{\Phi}$ whom RA is associated with DR1 and not DR4? and the use of a different gold preparation (aurow thioglucose) may explain these differences. Interest ingly, Israeli patients having generalised granulom annulare have an increased frequency of HLA B35, ${ }^{14}$ further supporting the association between this antigen and skin eruptions.

In Caucasians and in the Israeli Jewish population there is a linkage disequilibrium between B35 and DR1. The fact that we have previously observed a

Table 2 Frequency of class $I$ and II antigens in the various groups tested

\begin{tabular}{|c|c|c|c|c|c|}
\hline \multirow{2}{*}{$\begin{array}{l}\text { HLA } \\
\text { antigen }\end{array}$} & \multicolumn{3}{|c|}{ Gold induced side effects (group A) } & \multirow{2}{*}{$\begin{array}{l}\text { No side } \\
\text { effects } \\
(\text { group B) } \\
(n=40)\end{array}$} & \multirow{2}{*}{$\begin{array}{l}\text { Healthy } \\
\text { controls } \\
(\text { group C) } \\
(n=300)\end{array}$} \\
\hline & $\begin{array}{l}\text { Mucocutaneous } \\
(n=20)\end{array}$ & $\begin{array}{l}\text { Proteinuria } \\
(n=9)\end{array}$ & $\begin{array}{l}\text { Haematological } \\
(n=5)\end{array}$ & & \\
\hline $\begin{array}{l}\text { B35 (\%) } \\
\text { DR1 (\%) } \\
\text { DR3 (\%) } \\
\text { DR4 (\%) } \\
\text { DR5 (\%) }\end{array}$ & $\begin{array}{l}60^{*} \\
30 \\
11 \\
35 \\
35\end{array}$ & $\begin{array}{l}11 \\
22 \\
11 \\
33 \\
55\end{array}$ & $\begin{array}{l}20 \\
20 \\
20 \\
40 \\
40\end{array}$ & $\begin{array}{l}31 \cdot 5 \\
20 \cdot 3 \\
20 \cdot 0 \\
44 \cdot 4 \\
37 \cdot 0\end{array}$ & $\begin{array}{l}31 \cdot 3 \\
13 \cdot 7 \\
16 \cdot 5 \\
38 \cdot 3 \\
42 \cdot 5\end{array}$ \\
\hline
\end{tabular}


association between DR1 and RA and that in this disease B35 is associated with gold induced mucocutaneous lesions may indicate that indeed genes conferring susceptibility to RA and gold induced side effects are in linkage with this B35-DR1 haplotype. The mechanisms by which the presence of an HLA antigen is associated with the pathogenesis of a given disease are still unclear, however.

In conclusion, our results further confirm a strong association between mucocutaneous lesions induced by gold treatment and HLA-B35, despite the different genetic background of our population and the use of a different gold compound (aurothioglucose).

\section{References}

1 Stastny P. HLA-D and Ia antigens in rheumatoid arthritis and systemic lupus erythematosus. Arthritis Rheum 1978; 21: S139.

2 Stastny P. Association of the B-cell alloantigen DRw4 with rheumatoid arthritis. $N$ Engl J Med 1978; 298: 869-71.

3 Panayi G S, Wooley P H. B-lymphocyte alloantigens in the study of the genetic basis of rheumatoid arthritis. Ann Rheum Dis 1977; 36: 365-8.

4 Panayi G S, Wooley P, Batchelor J R. Genetic basis of rheumatoid disease HLA antigens discasc manifestations and toxic reaction to drugs. $\mathrm{Br}$ Med J 1978; ii: 1326-8.

5 Ferraccioli G, Peri F, Nervetti A, Ambanclli U, Savi M. Toxicity due to remission inducing drugs in rhcumatoid arthritis.
Association with HLA-B35 and Cw4 antigens. $J$ Rheumatol 1986; 13: 65-8.

6 Nusslein H G, Jahn H, Lösch G, Guggenmoos-Holtzman I, Leibold W, Kalden J R. Association of HLA-B35 with mucocutaneous lesions in rheumatoid arthritis patients undergoing sodium aurothiomalate therapy. Arthritis Rheum 1984; 27: 833-6.

7 Schiff B, Mizrachi Y, Orgad S, Yaron M, Gazit E. Association of HLA-Aw31 and HLA-DR1 with adult rheumatoid arthritis. Ann Rheum Dis 1982; 4: 403-4.

8 Terasaki P I, Bennaco D, Park M S, Ozturk G, Iwaki Y. Testing for HLA-A-B-C and DR antigens. Am J Clin Pathol 1978; 69: 103-20.

9 Mittal K K, Mickey M R, Signal D P, Terasaki P I. Sex typing for dermotransplantation. Refinement of microdroplet lymphocyte cytotoxicity test. Transplantation 1968; 6: 913-27.

10 Dequeker J, Van Wanghe P, Verdickt W. A systematic survey of HLA-A, B, C and D antigens and drug toxicity in rheumatoid arthritis. J Rheumatol 1984; 11: 282-6.

11 Scherak O, Smolen J S, Mayr W R, Mayrhofer F, Kolarz G, Thumb N J. HLA antigens and toxicity to gold and penicillamine in rheumatoid arthritis. $J$ Rheumatol 1984 ; 11: 610-4.

12 Bensen W G, Moore N, Tugwell P, D’Souza M, Signal D P. HLA antigens and toxic reactions to sodium aurothiomalate in patients with rheumatoid arthritis. J Rheumatol 1984; 11: 358-61.

13 Dahlquist S R, Ström H, Bjelle A, Möller E. HLA antigens and adverse drug reactions to sodium aurothiomalate and $D$ penicillamine in patients with rheumatoid arthritis. Clin Rheumatol 1985; 4: 55-61.

14 Friedman-Birnbaum R, Gideoni O, Bergman R, Pollack S. A study of HLA antigen association in localized and generalized granuloma annulare. Br J Dermatol 1986; 115: 329-33. 